\section{Exercise and sport for all}

Jim Aitken

According to the annual Edinburgh University Sports Union Club Survey, the standard of its fitness facilities is a key factor for many potential students in choosing a university. University of Edinburgh Sport \& Exercise, with Olympic medal-winning ambassadors such as Sir Chris Hoy (cycling) and Dame Katherine Grainger (rowing), contributes significantly to the University's reputation locally, nationally and internationally (see the University of Edinburgh's Strategic Plan 2016: Delivering Impact for Society).

In actual fact, sport has featured at the University for over 150 years. This was founded largely on traditional school sports played through a formal club structure, but not now. The University of Edinburgh's Scottish and UK pre-eminence (see The Times and Sunday Times: Good University Guide) has been built over the last 15 or so years, with the Director widening the focus from sport to health, fitness and exercise - 'modernising the offering' as he puts it. In the process he has radically changed and upgraded the physical facilities to enable and reflect this change and produce a better balance between 'sport' and personal 'health \& well-being'.

In 2004 the University's sports offer had around 8,100 members from across the University and community. The focus was very much on supporting students who came into the University with a pre-existing interest in sport and encouraging them

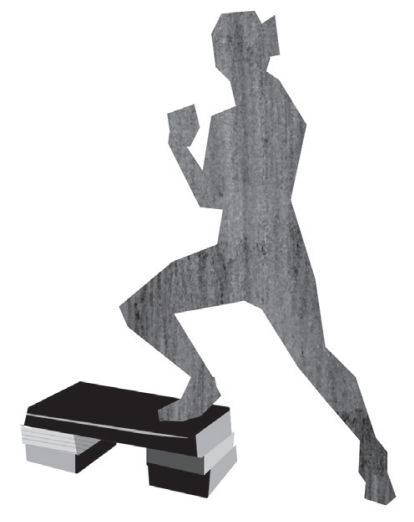

to continue their involvement through the University's 50+ sports clubs or via the recreational 'Intra-Mural' programme. This was further swayed by the largely sports bias of the University's facility mix. At the time, around 6,500 students were involved in sport and gym activity, the majority of whom were male (56\%).

For example, when members entered the University main sports centre at Pleasance, the first facilities they saw were eight squash courts, occupied - when they were at all - by (predominantly) male senior faculty "heading to middle age". Of course there was a modest gym provision that members could use - tucked away at the far side of the ground floor, about the size of one-and-a-half squash courts, in constant demand and cramped. This contrasted with the extensive provision for squash (8oo square metres of space) supporting a maximum of 16 people at any one time.

This made a very poor impression on potential students and new members, especially young women, reinforcing the stereotype that the University was seemingly prioritising its recreational facilities for middle-aged men, not for them.

Responding to student feedback and the clear imbalance, University Sport \& Exercise challenged this paradigm, rethought its core purpose, and drew up a change programme that moved the facility from a predominantly 


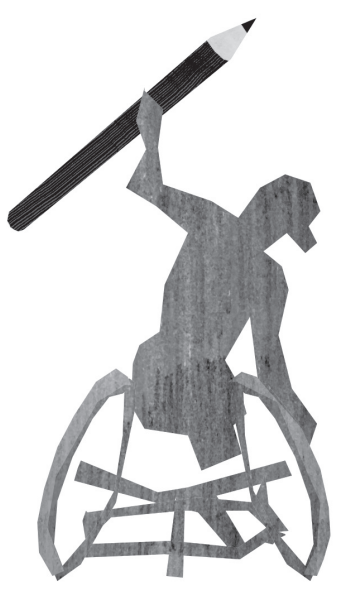

sport-based focus to celebrating and promoting exercise, health and fitness, for all. The change was additionally underpinned by Sport England and Sport Scotland facility guides on ideal occupancy levels of squash courts, which suggested the University had more courts than it needed for the size of its squash community.

The new approach of supporting health, fitness and exercise was planned, the design for a new space was drawn up; half of the squash courts were closed and the refit started - to loud protests from the users (see What have you done to my squash courts!).

This transition process did create a very unsettling time for University Sport \& Exercise's members and staff, but the results have been hugely positive. Within the first year, membership rose by 1,500, and gender balance approached 50:50 as more female students felt the sport \& fitness offer contained something appealing for them. More, the new gym space boasted a stunning design, and was located immediately on arrival to Pleasance - this presented a very dynamic, attractive and relevant option for students, and encouraged them to be more physically active. Sport \& Exercise has gone from strength to strength ever since, helped by the completion of an even more ambitious facilities extension plan in 2010. This has positioned the University as one of the UK's premier sport \& fitness providers, which is hugely pleasing for everyone involved.
Now in 2017, its membership is 18,700 and in 2016 it had an annual footfall of 800,000. Its student membership is $43 \%$ male and $57 \%$ female. This is fuelled by state-of-the-art facilities, with a raft of contemporary gyms, supportive staff, about 100 group-exercise classes each week, and affordable pricing - all within easy walk of the University's main city centre campus, and with a superb marketing and communications plan. That's all quite a change from 2004! The good news is that squash is still booming at the University!

\section{Initial Ingredients}

This recipe has two sets of ingredients. The first set are the ones used in the first change programme (2004); and the second are additional ingredients being used now, as a direct result of learning from the first round of changes.

- A huge dollop of confidence in your conviction to see change through, backed up by a robust set of evidence and the justification for change, including:

- Information and feedback from students;

- Independent statistics (Sport England and Sport Scotland reports).

- Clear and expressed values.

- A lived passion for exercise, health and fitness. 
- A visible way of tracking/ identifying impact.

\section{Additional Ingredients}

- Communication.

- Communication.

- Communication.

- Listening.

\section{Method}

1. Take the first three ingredients conviction + evidence, clear values, and passion - mix together and live them in yourself. This way you attract other passionate people to work with you.

2. Provide great service in great facilities:

a) Make the offering attractive to a diverse membership-gender, age, physical ability, status, ethnicity, locality. For example, there is a wide range of different interests, types of experience, levels of confidence, and current trends in fitness; and we need to cater for them all.

b) Design the new facilities so that they clearly demonstrate your values the moment a member walks into the space:

- A passion for exercise, health and fitness.

- Healthy bodies support healthy

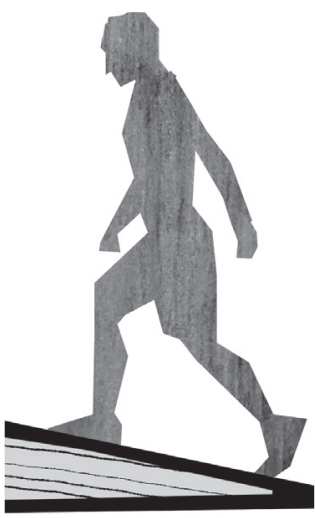

minds - and this is what the University is here to do.

- A safe and supportive space for all members to meet, mix, and learn.

- A place where everybody is welcome.

c) Deliver wide member choice, for example:

- Reaching inactive staff and students through the SPA programme (Support for Physical Activity) for people who want to become more active for their health. This may be achieved through a variety of activities including walking as well as gym and sport.

- Nurturing mind and body together through yoga and PIYO (pilates/yoga).

- $\quad$ Supporting all students through stress-buster activities around exam time, although we do lose the big hall to examinations!

- Fitness is personal. Everyone has individual tastes, needs and wants which are dynamic and ever-changing. So the offerings need to be regularly revisited to meet changing demands from customers: different times, types, lighter or more intense regimes. 
d) Offer out-of-the-ordinary member services, for example Sport \& Exercise has FASIC (Fitness Assessment and Sports Injuries Centre), a multidisciplinary sports injuries clinic, with podiatry, physiotherapy, massage, a doctor service, workshops and training courses. It also has dedicated spaces for archery, grappling, climbing, rowing, boxing, specialist gym areas, and lots more besides, including stunning changing rooms, with saunas. Don't be scared to experiment with your exercise offerings.

e) Set (exercise) menus can prove tiresome, and remember there are new approaches and recipes being tried in exciting new restaurants all the time, so be mindful of complacency and competition.

3. Link into research - for example, through the Healthy University project, University of Edinburgh students have the opportunity to carry out research that has benefits for their own development and that of Sport and Exercise.

4. Measure the results.

We now regularly add the missing ingredient - communication, communication and even more communication:
5. Communicate what the change programme is offering - what it is, why it is important to the University and its students, staff and community, and why you are passionate about it. If we'd done this in the first place, we'd have avoided the recipe What have you done to my squash courts! ever needing to be written!

6. Communicate what any shortterm discomfort might be, and communicate the long-term benefits.

7. Communicate to everyone and keep communicating: make no assumptions that they will have taken it on board and understood the first time they heard it.

8. Remember that communication is a two-way process, not just broadcast. Listen, and respond nimbly and speedily to feedback.

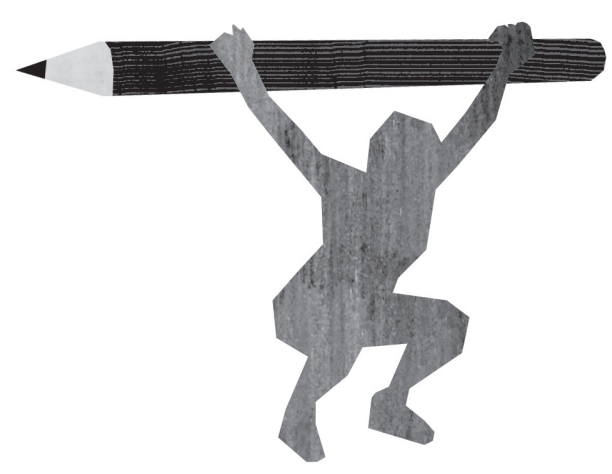

